\title{
O objetivo econômico da bandeira e sua natureza jurídica
}

\section{Moacir Benedito de Sousa}

\section{0 bandeirismo}

1 - 0 bandeirismo é um dos episódios mais apaixonantes de nossa história. Considerado por uns como um simples amontoado de aventuras e proezas, elevado por outros à posição de um acontecimento fundamental na formação da nacionalidade brasileira, o certo é que o movimento das bandeiras enche três séculos do nosso passado, e está a exigir novos estudos, a fim de que se faça luz sôbre muitos de seus aspectos, em razão da pobreza documental deixada pelos seus realizadores.

É verdade que estudiosos como Taunay e Ellis Júnior têm dedicado a vida à elucidação dos feitos heróicos dos paulistas; que pesquisas levadas a efeito por Azevedo MarQUes, Washington Luis e outros têm revelado documentos de grande valia para o estudo do nosso "episódio histórico mais brasileiro", no dizer de Cassiano Ricardo. “Já diversos poderosos sulcos revolvedores da verdade se abriram", assevera TAUNAX (1). E acrescenta: "É a insurreição contra os decretos do Destino que, como querendo obscurecer as ações dos devassadores do deserto, determinara a perda de dois terços da obra formidável do

(1) Afronso E. Taunay, Indios! Ouro! Pedras!, Companhia Melhoramentos de São Paulo, São Paulo, 1930, pág. 3. 
seu historiador, o homeriada Pedro Taques, como tão expressivamente the chama Oliveira Viana".

Mas não basta. Muito há que se fazer ainda neste terreno. O campo é vasto e a qualidade de seus cultivadores é das melhores. Novas luzes se farão, por certo, sôbre a obra desses pioneiros, dêsses "intrépidos moradores de S. Vicente, nos quais, ou por fôrça do fado, ou por desgraça da sua capitania e ventura das outras, sempre foi predominante a paixão de conquistar", segundo as palavras de Frei Gaspar, citados por Oliveira Viana (2).

2 - Há hoje uma acentuada tendência em denominar-se bandeiras a tôdas as expedições que, nos primeiros séculos de nossa história, penetravam nas selvas visando a caça do índio ou a pesquisa de ouro e pedras preciosas. No entanto, os autores registram diferenças entre bandeira, entrada e jornada. Explica Alfredo Ellis Júnior que o bandeirismo pesquisador "empregou a "entrada" e não a "bandeira" que se destacava daquela, pelo fato de que esta era um grande corpo militar de homens armados em ofensiva, para o fito de apresar índios, enquanto que a "entrada" era um pequeno corpo de homens, uns 50 mais ou menos, manejando o aluvião e a bateia em vez de arcabuz que excepcionalmente os armava, em defensiva, com o fito de descobrir as riquezas mineralógicas" (3). Ensina ainda o renomado historiador e sociólogo paulista que as entradas eram, na sua maioria, oficiais e tiverám lugar no Norte, enquanto que as bandeiras eram sempre particulares e se formavam sempre no planalto.

Dessa opinião participa também Basílio Magalhães, ao afirmar na sua Expansão Geográfica do Brasil até o

(2) Oliveira Viana, Populações Meridionais do Brasil, Coleção Brasiliana, Companhia Editôra Nacional, 3a Edição, São Paulo, 1933, págs. 99 e 100 .

(3) Alfredo Ellis Júnior, $O$ Bandeirismo na Economia do Século 17, in Curso de Bdndeirologia, Departamento Estadual de Informaçães, São Paulo, 1946, págs. 74 e 75. 
fim do século XVII que a bandeira é um fenômeno rigorosamente paulista e que a denominação sòmente se aplica às expedições que se organizavam em São Paulo, e que iam pelo sertẫo a dentro devassando terras, cavando minas ou preando selvagens. As entradas, estas tinham um cunho oficial. Eram expedições que os governadores, ou quaisquer dos prepostos do Govêrno, formavam para o preamento do índio ou visando as riquezas minerais. Ainda na opinião daqueles autores, enquanto que o ciclo das bandeiras realizou-se além da linha de Tordesilhas, até os contrafortes andinos, o ciclo das entradas teve por teatro a zona do litoral, quase todo dentro da linha fixada pela Bula de AleXaXdre VI.

Todavia, a distinção proposta entre bandeira e entrada não tem consistência. Ambas as denominações indicam a mesma expedição, variando conforme o gôsto do historiador. $O$ caráter oficial que se pretende dar à entrada também é falho como elemento distintivo, visto que muitas expedições ao sertão denominadas por alguns de "entradas" eram armadas por particulares. É o que se depreende dos documentos da época, que não faziam distinção entre entradas e bandeiras, usando ainda outras denominações, conforme nos dá conta Alcântara Machado: “à incursão os documentos paulistas do tempo chamam "entrada", "jornada", "viagem", “companhia", "descobrimento" e mais raramente "frota" (4).

Alguns autores insistem em distinguir das expedições já referidas as "jornadas". Estas seriam feitas na direção do Norte ou Nordeste, visando tanto os objetivos das "bandeiras" como a guerra tão sòmente.

Recorda-se, a proposito, que a expedição enviada pelo Govêrno ao Norte a fim de expulsar os francêses do Maranhão, recebeu a denominação de "Jornada Milagrosa".

(4) Alcântara Machado, Vida e Morte do Bandeirante, São Paulo, 1929, pág. 260. 
As "monções", estas sim, distinguiam-se das expedições anteriores. Tinham por estrada o rio e visavam as lavras e o povoamento de seus arredores. "A monção - diz ALFREDo Ellis JúnIoR - era uma grande massa de gente, homens, mulheres, crianças, velhos, etc., que povoadora se locomovia como em comboios, pela via fluvial, com data e itinerários certos, para os pontos de fixação junto às lavras, povoando largas zonas em tôrno delas, não só se entregando à atividade mineradora, mas, também, às correlatas" (5).

3 - Por que foram denominadas bandeiras as expedições dos homens do planalto piratiningano? A origem do vocábulo como agrupamento de sertanistas é ainda passível de discussões. Capistrano de Abreu explica o uso do têrmo, relacionando-o com a bandeira, insignia ou estandarte que certas tribos tupis alçavam por ocasião das guerras. Alcântara Machado também liga o emprêgo da palavra bandeira à insígnia, afirmando que "nas empresas de caráter militar mais acentuado e de maior importância, os expedicionários iam classificados em companhia, e cada companhia levava o seu pendão" (6). Augusto DE Lima Júnion, por sua vez, afirma que, em sua origem, bandeira era uma forma de milícia rural, uma instituição portuguêsa da Idade Média, que trazia como insígnia um pedaço de pano (7).

$\mathrm{O}$ fato é que muitas dessas expedições levavam consigo um estandarte quando penetravam pelo sertão, e isso deu ensêjo a que muitos historiadores vissem em tal costume a origem do têrmo. " $\mathrm{E}$ é assim — afirma Belmonte com a bandeira desfraldada no recesso das florestas pávi-

(5) Alfredo Ellis Júnior, art. cit., pág. 75.

(6) Alcântara Machado, ob. cit., pág. 259.

(7) Augusto Lima Júnior, Capitania de Minas Gerais, Zélio Valverde, Rio, 1943, pág. 38. 
das, que os vemos passar, rumo ao desconhecido, para a fortuna ou para a morte" (8).

Outros, entretanto, divergem dessa explicação. Artur Gaspar Viana acha que o vocábulo bandeira é originário de "bando", que nada mais era do que um edital que se afixava nas praças públicas, dando ciência à população dos nomes recrutados para as penetrações no sertão.

Lindolfo Gomes (9), por seu turno, opina como mais aceitável a origem espanhola do vocábulo, visto que em castelhano a palavra "bandera" designa "la partida destinada a hacer recrutas". Tal asserção encontra certo apôio histórico, pois foram os jesuitas espanhóis os iniciadores dessas expedições, com a finalidade de libertar os indios, quando prisioneiros de tribos adversárias.

Parece-nos, entretanto, mais plausível a explicação que relaciona a palavra "bandeira" no sentido de expedição de sertanistas a uma companhia de cunho militar, cujo estandarte ou insígnia de uso quase obrigatório, daria o nome de "bandeira" a êsse agrupamento.

Quando foi empregado, pela primeira vez, o têrmo bandeira na sua acepção de tropa sertanista? Alcântara MAcHADo remonta tal emprêgo ao ano de 1726, dizendo que "um documento do padre JoÃo Gomes,' superior da missão jesuítica de Paranaguá, menciona o fato do povoador de Laguna ter despedido uma "bandeira" com 30 pessoas, cujo cabo é JoÃo de Magalfĩ̃es, a povoar o Rio Grande" (10). Belmonte recua mais no tempo o uso do vocábulo, ao afirmar que já aparece num requerimento que os oficiais da Câmara, em 1612, enviaram ao Governador da Capitania, e no qual se lia:" ... o dito administrador os anexa com excumunhões sendo a jurisdição real de sua

(8) Belmonte, No Tempo dos Bandeirantes, Departamento de Cultura de São Paulo, 1939, pág. 246.

(9) Augusto de Lima Júnion, ob. cit., pág. 38.

(10) Alcântara Machado, ob. cit., pág. 260. 
magestade e sua justiça não indo contra a ninguem nem levantam bandeira" (11).

4 - 0 banderismo é um fenômeno tipicamente paulista. Se è verdade que houve em outras regióes da colônia expedições de sertanistas, a ponto de Capistrano DE ABREU classificar as bandeiras em paulistas, baianas, pernambucanas, maranhenses e amazônicas, o certo ẻ que sòmente no planalto piratiningano elas tiveram sua perfeita caracterização. BASílio dE MAGaLHães é peremptório a êsse respeito: "a bandeira é um fenômeno rigorosamente paulista e a denominação sòmente se aplica às expedições que se organizavam em São Paulo" (12).

$O$ bandeirante é um produto do planalto paulista. $O$ meio físico, impedindo a ação humana isolada, deu características próprias ao seus habitantes, moldando-lhes também seu temperamento e seu caráter. Os elementos raciais e histórico-sociais, convergindo para o fator ecológico, completaram o quadro formador do homem sertanista. E assim, com a primeira geração de mamelucos iniciava-se $o$ bandeirismo nas terras de Piratininga, como "uma fatalidade de ordem biológico-climatérica", no dizer de Euxis JÚNIOR (13).

5 - Gilberto Freyre, em sua notável obra Casa Grande \& Senzala, procura explicar a mobilidade do bandeirante como conseqüência de uma suposta influência semítica nas populações da zona Meridional do Brasil. Dessa opinião participam, entre outros, Alberto Torres e Paulo Prado, afirmando êste que "de fato nenhum outro sítio do território colonial oferecia melhor acolhida para a emigração

(11) Belmonte, ob. cit., pág. 246.

(12) Basíllo Magalfães, Expansião Geográfica do Brasil até - fim do século XVII, Coleção Brasiliana, Companhia Editôra Nacional, São Paulo, pág. 19.

67.

(13) Alfaedo Ellis Júnion, São Paulo e a sua Evolução, pág. 
judia”, e que "em São Paulo não os perseguia êsse formidável instrumento da inquisição, que nunca chegou à capitania do Sul" (14).

Realmente, nos primeiros anos da colonização do Brasil, alguns dos chamados "Cristãos-Novos", isto é, "judeus convertidos à fôrça ao cristianismo", requereram a $\mathrm{D}$. Manoel o arrendamento de terras na sua colônia da América, com o fito de realizar sua penetração e explorar o comércio de pau-brasil. Em 1503 chegava uma frota conduzindo os primeiros elementos judeus, que forneceriam braços e capitais aos primitivos donatários das capitanias do Norte. Anos depois, introduziram os israelitas, naquela região, a industria do açúcar, que tão marcante influência teria no desenvolvimetno do Brasil nos séculos XVI e XVII. Neste particular, estão de acôrdo renomados sociólogos e historiadores patrícios, como Gilberto Freyre, Pedro Calmon, Hélio Viana, Ernesto de Moraes e outros.

Todavia, discordam vários autores, e com êles estamos de acôrdo, que a mobilidade, o nomadismo da gente bandeirante seja decorrente da influência do sangue semita. Em primeiro lugar, revelam dados da época, que as correntes emigratórias israelitas se concentraram no Nordeste, zona de grande prosperidade, que of erecia flagrante contraste com a pobreza da Capitania de São Vicente. Financiando e construindo engenhos naquela região, os judeus não procurariam o Sul, pondo em choque os seus interêsses mais imediatos. Por outro lado, faltam razões a Gilberto Freyre quando explica que êles fugiam do Santo Ofício, que se estabelecera na Bahia e Pernambuco, rumo a zona Meridional da colônia, visto que gozavam da condição de "Cristãos-Novos". Se muitos israelitas se estabeleceram no Sul por ocasião do período de colonização do Brasil, não o fizeram, entretanto, em proporção tal que viesse influir na formação do bandeirante.

(14) Paulo Prado, Paulistica, São Paulo, 1925, pág. 20. 
Fizemos referências à participação ou não do sangue semita na constituição étnica dos sertanistas de São Paulo, por julgarmos tal estudo um elemento de valia na elucidação do objetivo econômico da bandeira.

É ao sangue indígena que devemos a mobilidade do paulista, o seu nomadismo pelo interior do sertão, o seu desejo constante de vencer obstáculos, de abrir picadas, de sentir a sensação de vencer o desconhecido.

Outro assunto que nos interessa neste estudo é o que se refere às qualidades do sertanista como chefe, seu prestígio sôbre os demais membros da expedição, sua autoridade sôbre tôda a bandeira em marcha.

A explicações apresentadas pelos diversos estudiosos do assunto são as mais diversas. Oliveira Viana (15) baseia tal posição na sesmaria, no latifúndio, assim se expressando: "O prestígio, ascendência, o poder da nobreza paulista é de formação puramente nacional e tem uma base inteiramente local. É sôbre a sesmaria, sôbre o domínio rural, sôbre o latifúndio agrícola e pastoril que êle se assenta". Dentro dêsse ponto de vista, o renomado sociólogo chega a definir a bandeira como sendo "um fragmento do latifúndio".

Esta explicação é inaceitável, pois foge à realidade histórica. Alfredo Ellis Júnior, Taunay e Alcântara MachaDo discordam de Oliveira Viana. Ao contestá-lo, diz o primeiro que os bandeirantes sempre se bateram pelo regime da "pequena propriedade".

Pensamos que não é na propriedade imobiliária que iremos encontrar a explicação para o prestígio do chefe de bandeira. Cassiano Ricardo diz mesmo, na sua Marcha para Oeste, que "bandeira e propriedade imobiliária não rimam bem. O nenhum apêgo bandeirante à idéia de propriedade imobiliária é a primeira condição para a sua mo-

(15) Oliveira Viana, ob. cit., págs 99 e segs. 
bilidade" (16). Achamos que a explicação dada por JoAQUim Ribeiro (17) é a mais aceitável. Diz êle que a ascendência do chefe bandeirante é devida à fusão de dois elementos sociais: um, lusitano, patriarcal, o "pátrio poder" no seu conceito clássico, que possuia ampla função social; e outro, o americano, selvagem, o "caciquismo".

6 - Grande foi, sem dúvida, o papel desempenhado pelo bandeirismo na construção do Brasil de hoje. "Para mim - diz Cassiano Ricardo - a bandeira não é apenas o episódio histórico mais brasileiro. Além de haver traçado o retrato geográfico do Brasil, é um fenômeno social e político que ajuda a esclarecer muitas das nossas instituições atuais" (18).

Qual foi, entretanto, o objetivo dêsse gigantesco movimento? Para nós, foi econômica, mercantil, a principal finalidade da bandeira. Nas páginas que se seguem, procuraremos dar as razões dessa posição que adotamos, hoje também defendida por grande número de autores, para daí auferirmos a natureza jurídica da bandeira.

Essas razões são reveladas, em sua essência, pelas duas grandes fases do bandeirismo: o ciclo da caça ao índio e o ciclo do ouro.

\section{0 ciclo da caça ao índio}

Já na primeira metade do quinhentismo, a riqueza do Nordeste oferecia grande contraste com a miséria do planalto vicentino. Pelas estatísticas demográficas conhecidas, inclusive a do P'e. Anchieta, verifica-se que a Capitania de

(16) Cassiano Ricardo, Marcha para Oeste, 10 Vol., 2a Edição, Livraria José Olympio Editôra, Rio, 1942, pág. 57.

(17) JoAquim Ribeiro, Folklore dos Bandeirantes, Livraria José Olympio Editôra, Rio, 1946, pág. 29.

(18) Cassiano Ricardo, ob. cit., pág. 26. 
São Vicente era 20 vêzes inferior ao Nordeste e apenas $3 \%$ do total do Brasil.

Uma das razões dêsse atrazo residia no fato do paubrasil, a maior fonte de riquezas no início da colonização Brasil, sòmente desenvolver-se do Cabo Frio para o Norte. E por quê? Gandavo no seu Tratado da Terra do Brasil, assim esclarece: “... o qual se mostra claro, ser produzido de quentura de sol e criado, com a influência de seus raios, porque quanto mais próximo da tórrida zona e quanto mais perto da ilha equinoxial tanto é mais vivo e da melhor qualidade. É esta a causa porque o não há na Capitania de S. Vicente, nem daí para o Sul".

Mas a razão principal residia na grande prosperidade atingida pela cultura da cana de açúcar nas terras do Nordeste, em desacôrdo com as miseráveis plantações dessa gramínea na zona Meridional da colônia. Alfredo Fúlus JúNIOR assim explica êsse contraste: "A distância mais curta, de 2 milhares de quilômetros dos centros consumidores da Europa; as cargas de importação, causando um frete muito mais baixo; um clima mais quente; terras massapés, talvez mais ubertosas para o plantío da cana tudo isso deu ao Nordeste a primazia econômica". (19)

Dessa maneira, sem fonte básica de riqueza, o planaltino contemplava o enriquecimento dos seus irmãos do Nordeste, onde prosperava intensamente a indústria do açúcar. verdade que $S$. Vicente conheceu primeiro a plantação de cana de açúcar, com Martim Afonso, em 1532. O Nordeste só mais tarde, com Duarte Coelho, iniciou essa cultura. “Travou-se - diz Alfredo Eldis Júnior - entre as duas regiões brasíleiras uma luta econômica que eu chamo de primeira batalha do açúcar. Foi uma batalha surda, anônima, sem os ecos rimbombantes das batalhas militares, sem as galopadas heróicas, sem os lampejos das armas

(19) Alfredo Éluls Júnior, Meio Século de Bandeirismo, Coleção Brasiliana, Companhia Editôra Nacional, São Paulo, 1948, pág. 21. 
metálicas, sem os estrépitos ensurdecedores dos soldados em marcha suarentas, sem os branidos dos vitoriosos e o ranger de dentes raivosos dos vencidos, sem o sangue dos moribundos, sem o gemido dos feridos, mas com conseqüências imensas para o futuro. Para S. Vicente, a miséria; para o Nordeste, a riqueza. Êsse foi o binômio fatal que deveria presidir tôda a história do Brasil" (20).

8 - A mão de obra era, entretanto, sério problema para os engenhos daquela região. $O$ tráfico do africano não tinha atingido ainda o ponto desejado para resolver a premente necessidade do braço para a indústria. $\mathrm{A}$ introdução do escravo negro no Brasil, dizem as fontes, foi iniciada a partir de 1549, embora em 1535 alguns africanos já trabalhassem nos poucos engenhos de S. Vicente, segundo nos dá conta Roberto Simonsen (21).

Exportando o Nordeste na primeira metade do seiscentismo, conforme Alfredo Ellis Júnior (22), apoiado em Simonsen, cêrca de 2.500 .000 arrobas anuais de açúcar, exigia também 41.500 escravos. Com os necessários ao trabalho doméstico, êsse total atingiu a casa dos 60.000 . Sendo o desgaste médio do escravo calculado em 5 anos, resulta que o Nordeste precisava, anualmente, de 12.000 escravos.

Aonde buscá-los? A Äfrica, cuja mercadoria era mais cara que a americana - segundo Simonsen, no período de maiores preços, o indígena alcançava de $4 \$ 000$ a $70 \$ 000$ e o negro valia de $50 \$ 000$ a $300 \$ 000$ - só fornecia cêrca de 4.000 escravos por ano. $O$ próprio Nordeste não podia também abastecer seus engenhos da necessária mão de obra. Restava sòmente o recrutamento do indio, reduzido à escravidão, em outras regiões do Brasil.

(20) Alfredo Ellis Júnion, ob. cit., in Curso de Bandeirologia, pág. 60 .

(21) Roberto C. Simonsen, História Econômica do Brasil, Vol. I, Coleção Brasiliana, 2a Edição, São Paulo, 1944, pág. 198. (22) Alfredo Ellis Júnion, art. cit., in Curso de Bandeirologia, pág. 60 . 
Surge, então, na Capitania de S. Vicente o bandeirismo apresador. Tem início no planalto piratiningano o episódio que Paulo Prado denominaria "a página negra das bandeiras" (23) e HandelmanN, citado por TaUnay, qualificaria de "uma das mais negras manchas da história brasileira e para a qual não há nenhuma desculpa" (24). Não possuindo outra fonte de riquezas, o homem piratiningano lança-se pelo sertão à caça do gentío, realizando uma epopéia, sem paralelo na história do continente, de conseqüências formidáveis, mas imprevisíveis.

9 - Foi o selvagem brasileiro um bom escravo? Não. O negro africano, sob todos os pontos de vista, foi superior ao brasilíndio nos trabalhos das lavouras e das indústrias. GiLberto Freyre retrata muito bem a diferença entre o negro e o índio nas labutas dos engenhos daquela época, ao afirmar que a contribuição do selvicola "foi formidável, mas só na obra de devassamento e de conquista dos sertões, de que êle foi o guia, o canoeiro, o guerreiro, o caçador e pescador. Muito auxiliou o índio ao bandeirante mameluco, os dois excedendo ao português em mobilidade, atrevimento e ardor guerreiro; sua capacidade de ação e de trabalho falhou, porém, no rame-rame tristonho da lavoura de cana, que só as reservas extraordinárias de alegria e de robustez animal do africano tolerariam tão bem. Compensou-se o índio, amigo ou escravo dos portuguêses, da inutilidade no esfôrço estável e contínuo pela extrema bravura no heróico e militar". (25) E mais adiante: "Enquanto o esfôrço exigido pelo colono do escravo índio foi o de abater árvores, transportar os toros aos navios, granjear mantimentos, caçar, pescar, defender os senhores contra os selvagens inimigos e corsários estrangeiros,

(23) Paulo Prado, ob. cit., pág. 54.

(24) A. E. Taunay, História das Bandeiras Paulistas, Tomo I, Edições Melhoramentos, São Paulo, 1951, pág. 20.

(25) Gilberto Freyre, Casa Grande \& Senzala, Livraria José Olympio Editôra, 1 Vol. 7a Edição, Rio, 1952, pág. 221. 
guiar os exploradores através do mato virgem —o indigena foi dando conta do trabalho servil. Já não era o mesmo selvagem livre de antes da colonização portuguêsa; mas esta ainda não o arrancara pela raiz do seu meio físico e do seu ambiente moral; dos seus interêsses primários, elementares, hedônicos; aquêles sem os quais a vida se esvaziaria para êles de todos os gostos estimulantes e bons: a caça, a pesca, a guerra, o contacto místico e como que esportivo com as águas, a mata, os animais. Ésse desenraizamento viria com a colonização agrária, isto é, latifundiária; com a monocultura, representada principalmente pelo açúcar. $O$ açúcar matou $o$ índio. Para livrar $o$ indígena da tirania do engenho é que o missionário o segregou em aldeias. Outro processo, embora menos violento e mais sutil, de extermínio da raça indígena no Brasil: a sua preservação em salmoura, mas não já a sua vida própria e autônoma.

Às exigências do novo regime de trabalho, o agrário, o índio não correspondeu, envolvendo-se numa tristeza de introvertido. Foi preciso substituí-lo pela energia moça, tesa, vigorosa do negro, êste um verdadeiro contraste com o selvagem americano pela sua extroversão e vivacidade". (26).

$O$ insucesso do índio nos trabalhos da lavoura e da indústria, deve-se ao fato de ter sido muito brusca a passagem do nomadismo à sedentariedade. O indio "sentiu" a sua transformação de trabalhador esporádico em homem de atividade contínua. O resultado foi revelar-se no sistema econômico do colonizador um ser apático que teve que ser substituido pelo negro.

10 - Embora denunciem os jesuitas que a preação do índio antecedera à chegada dos colonizadores, o certo é que no início, os novos ocupantes da terra brasileira dispensaram um generoso tratamento aos gentios. E foi dentro

(26) Gilberto Freyre, ob. cit., pág. 316. 
dêsse espírito que Pero Vaz de Caminha levou ao conhecimento de seu soberano suas impressões sôbre os nossos selvícolas, segundo a versão em português moderno feita por Carolina Michaelis: "Êsses índios parecem gente de uma tal inocência que, se se pudesse entender sua fala e êles a dos portuguêses, seriam cristãos, visto que não têm nem entendem crença alguma, segundo as aparências". E mais adiante: "O melhor fruto, entretanto, que se pode tirar, será creio eu, o de salvar êsse povo, e é a principal semente que Vossa Alteza deve espalhar sôbre esta terra" (27).

Essa atitude, entretanto, teve pouca duração. O sentimento de dominação que presidiu tôda a atividade colonizadora dos portuguêses, fêz com que êles lançassem logo sôbre os índios um olhar de senhor. E a escravidão vermelha iniciava-se nas terras brasileiras. Contam os historiadores que, já no ano de 1511, a nau "Bretoa", carregada de pau-brasil, levava também para Portugal 30 índios capturados nas selvas da colônia. Por coincidência, foi nesse mesmo ano que pisaram o solo da América, nas Ántilhas, os primeiros negros, como produtos do tráfigo regular africano.

Era do interêsse dos conquistadores para justificar suas atrocidades, inclusive a matança do índio, pintar o povo conquistado como não pertencente à raça hưmana, deprimindo-o o mais possível. A tal ponto chegou a desumana investida dos colonizadores sôbre os selvícolas, que, em 9 de Junho de 1537, o PaPa Paulo III reconhecia solenemente os primitivos habitantes da terra como verdadeiros homens, através da famosa bula Universibus Christi fidelibus, de cujo texto nos dá conta João Francisco LisbôA, no seu Jornal de T'imon: "Chegando á notícia do sancto padre que nas Indias então recentemente descobertas, tanto ao occidente como ao meio-dia, eram os respec-

(27) Carolina Michaelis de Vasconcelos, Histórid da Civilização Portuguêsa no Brasil, págs. 60 e segs. 
tivos indigenas tractados como brutos, e havidos por inhabeis para a fé catholica; e sob capa de que eram incapazes de recebe-la, os reduziam e punham em dura servidão, affligindo-os e opprimindo-os em tanto extremo, que ainda aquella em que traziam as suas bestas, não lhe eram comparável; obra tudo do commum inimigo do genero humano, que suggeria estas doutrinas e procedimentos a ministros seus, por onde se impedisse a propagação da fé por todas as gentes sem excepção, porque todas são igualmente capazes para a receber. Em vista do que, elle sancto padre, que fazia as vezes de Deus na terra, e tinha por officio e estreita obrigação reduzir ao seu rebanho as ovelhas que andassem perdidas e desgarradas fóra delle, determinava e declarava por auctoridade apostolica que os indios eram verdadeiros homens com os mais, e não só capazes da fé de Christo, senão propensos a ella, segundo chegara a seu conhecimento; e sendo assim, tinham todo o direito á sua liberdade, da qual não podiam nem deviam ser privados, e tam pouco do dominio dos seus bens, sendo-lhes livre logra-los e folgar com elles, como melhor lhes parecesse, dado mesmo que ainda não estivessem convertidos. Pelo que os ditos indios, e mais gentes só se haviam de attrahir e convidar á fé de Christo com a pregação da palavra divina, e com o exemplo de boa vida, sendo irrito, vão, nullo, sem valor nem firmeza, todo o obrado em contrario da presente determinação e declaração apostólica" (28).

A soleníssima declaração do Santo Padre não encontrou, todavia, ressonância no coração do conquistador lusitano, pois os excessos continuavam, dando lugar a que El-Rei D. SEbastião, em 20 de Março de 1570, "informado dos abusos que nessa materia se haviam introduzido, promulgava também uma lei, prohibindo os captiveiros que

(28) João Francisco Lis'Boa, Obras, Volume II, São Luiz do Maranhão, 1865, págs. 277 e 278. 
chamou illicitos, ou decretando a liberdade dos indios, com as seguintes excepções:

$1 .^{\circ}$ - Os que fossem tomados em justa guerra, feita com licença d'el-rei, ou do governador do Brasil;

$2^{\circ}$ - Os que salteassem os portugueses ou outros gentios para os comer" (29).

Essa lei foi revogada por outra de 11 de Novembro de 1595, promulgada por FeLIPE II de Castela e I de Portugal, determinando que sòmente seria admitido o cativeiro dos índios aprisionados em guerra. Em 5 de Junho de 1605, diz J. F. LisBoA, "entendendo el-rei a que sem embargos das declarações da lei de 1595, continuavam os captiveiros, com grave detrimento das fazendas do estado, e grandes inconvenientes contra o serviço de Deus e o seu, e consciencia dos que assim captivavam os indios, houve por bem declara-los inteiramente livres, para que em nenhum caso se pudessem captivar; porque, posto que por algumas razões justas de direito fosse permitido em alguns casos introdusir o captiveiro, as razões em contrario eram de muito maior peso, mormente no tocante á propagação da fé, e assim se deviam antepôr a todas as mais" (30).

Outras duas bulas papais, a de Urbano viII e a de BENEDITo xiv, foram também publicadas, e dirigidas especialmente aos colonizadores do Brasil (a bula do Papa PAulo III referia-se mais aos castelhanos) e mamelucos pregando a conversão e liberdade dos índios.

Grande foi a legislação sôbre o índio nos 3 primeiros séculos de nossa história. João Francisco Lisboa e PerdiGÃo Malheiros (31) citam cêrca de 60 leis, cartas régias, provisões, alvarás, regimentos, etc., referentes ao nosso selvícola, publicados naquele periodo.

(29) Joño Francisco Lisboa, ob. cit., pág. 279.

(30) João Francisco lisboa, ob. cit., págs. 280 e 281.

(31) Perdigão Malheiros, A Escravidấo no Brasil, Parte II, Tipografia Nacional, Rio, 1867. 
11 - O bandeirismo ofensivo vai de 1562 até 1696 , tendo seu apogeu no espaço compreendido entre 1628 e 1680. Seu marco inicial, pràticamente, foi a bandeira de Nicolau Barreto.

Embora involuntàriamente os jesuitas tiveram participação destacada no apresamento. Em suas "reduções", especialmente na de Guairá, destruida em 1628 por ANTônio Raposo Tavares, êles amansaram e cristianizaram centenas de índios, preparando assim a matéria prima para a indústria bélico-econômica dos paulistas. "Elimine-se a sua ação, por uma abstração - diz Ellis JúNior - e o bandeirismo de apresamento teria tomado uma feição muito diferente, pois teria sido muito menor e menos intenso do que foi, com profunda repercussão no Nordeste, bem como na produção de açúcar em geral" (32).

O bandeirismo apresador constitúi a "idade heróica do planalto", no dizer de Eluss Júnion, e suas conseqüências mudaram o curso de nossa história, da qual para muitos é êle a sua "página mais negra".

\section{O ciclo do ouro}

12 - A descoberta do ouro nas Gerais foi uma fatalidade histórica. Os elementos para a sua concretização lentamente se conjugavam e se reforçavam no último quartel do século XVII. O bandeirismo apresador preparara o terreno para o bandeirismo minerador. Nas suas arremetidas pelo sertão em busca do gentío, os paulistas exterminaram as tribos mais ferozes e rebeldes, rasgaram caminhos em tôdas as direções, abriram e limparam o sertão para as pacíficas bandeiras pesquisadoras de ouro e pedras preciosas. Estas nada mais fizeram do que explorar o campo preparado.

(32) Alfredo Ellis Júnior, Meio Século de Bandeirismo, pág. 52. 
Com o arrefecimento do bandeirismo preador, naquele findar de século, em razão, principalmente, da crise na produção açucareira do Nordeste, motivada pela concorrência das Antilhas, o paulista foi impelido a procurar outra atividade. Por outro lado, Portugal em meio à grave situação financeira decorrente da perda do seu mercado consumidor de açúcar, e ainda com a cobiça avivada pelas descobertas do ouro realizadas pelos espanhóis no México e Peru, procurou por tôdas as maneiras incentivar a pesquisa mineralógica em suas terras da América e da África. Essas circunstâncias levaram o homem do planalto vicentino à descoberta do ouro.

Éra o paulista o mais indicado para tão difícil missão. Além de suas qualidades inegualáveis de sertanista, possuía também alguns conhecimentos de mineração, adquiridos na extração de ouro de lavagem nas minas de Iguape, Jaraguá e Paranaguá. Esperar que as jazidas auríferas fossem encontradas por funcionários de S. Majestade era perder tempo. Só os paulistas poderiam levar a cabo tal empreitada. Assim sendo, em 25 de Março de 1693, o então Governador do Rio de Janeiro, Antônio Pais de Sande, envia à metrópole um relatório sôbre a questão, aconselhando um melhor entendimento com os homens de Piratininga, declarando, segundo TAUnay, que "expedições sertanistas escusado seria no Brasil entregá-las a quem quer que fosse a não ser a paulistas. Eram os paulistas homens sobremodo suscetíveis. Com muito tato devia S. Majestade tratar tão altanados súditos. Convinha acenar-lhes com mercês consideráveis e honrarias e a perspectiva da aliança de suas filhas a moços de casas fidalgas do Reino, honrados, embora pobres" (33).

E é nesse sentido que, em 27 de Setembro de 1644, d. Afonso vi se dirigia aos paulistas, e especialmente ao destemido e respeitado Fernão Dias Pais. Nessa carta,

(33) Affonso E. Taunay, História das Bandeiras Paulistas, Tomo I, pág. 213. 
segundo nos dá conta o mesmo Taunay, em outra obra (34), dizia o monarca: "Hei de ter muito particular lembrança de tudo o que obrardes nesta matéria para vos fazer a honra e mercê que saibaes merecer". O "Governador das Esmeraldas" recebera ainda outras cartas autografadas pelo punho real. Na de 25 de Fevereiro de 1674, o futuro PEDro II, dizia-lhe: "Quererá Deus que por vosso meio se efetúi o descobrimento das minas para melhoramento desta coroa e suas conquistas", e mais: "O que me pareceu agradecer-vos dignou-se S. Alteza afirmar fazendo a restrição de que quando tivesse efeito o que se desejava neste negócio poderia Fernão Dias esperar da real munificiência tôda a mercê e acrescentamento" (35).

$\mathrm{E}$ assim os paulistas partiram novamente para o sertão. Outra empreitada. Novas lutas. Finda-se o ciclo bandeirante da caça ao indio, em que pontificavara como expressão máxima o inegualável Antônio Raposo Tavares, para iniciar-se o ciclo do ouro, que teria em Fernão Dias Pais sua principal figura. De apresadores de indios, passam os bandeirantes a revolver o solo da colônia em busca de ouro e de pedras preciosas.

13 - Divergem os historiadores a respeito da data exata da descoberta do ouro e do nome de seu revelador. $O$ ano indicado vai de 1693 a 1696 . Quanto ao descobridor, vários nomes são citados pelos autores, sem que a maioria consiga fixar-se em um só: BARToloMeU Bueno de Siqueira, Carlos Pedroso da Silveira, Antônio Rodrigues ArzÃo, o mulato apontado por Antonil, Garcia Rodrigues, Borba Gato e outros. Na verdade, o que importa é ressaltar que a descoberta do ouro é fato que não deve ser atribuido a êste ou àquele. Foi a resultante do esfôrço de várias gerações e de fatôres geográficos, econômicos e políticos. Tinha que acontecer mais cedo ou mais tarde.

(34) Affonso Taunay, Indios! Ourol Pedras!, pág. 49.

(35) Affonso Taunay, Indios! Ouro! Pedras!, pág. 49. 
Por isso, repetimos: a descoberta do ouro nas Gerais foi uma fatalidade histórica.

Com sucessivos descobrimentos, a produção aurifera atinge seu apogeu em 1760, declinando em seguida, para tornar-se insignificante no final do século XVIII.

14 - A colônia sente os efeitos econômicos e sociais da fase de mineração. A febre do metal precioso contamina milhares de pessoas. $O$ sertão é tomado de assalto por dezenas de bandeiras. 0 litoral e as capitanias agrícolas se despovoam ràpidamente. A indústria do açúcar, já em crise, entra em franca decadência. Um êxodo sem precedentes afeta tôda a cultura de Pernambuco e Bahia, pois os plantadores passam a vender por alto preço seus escravos, para atenderem às necessidades sempre crescentes da mineração. Em pouco tempo se forma uma grande concentração em tôrno das minas, de que Antonil nos dá notícia: " dizem que mais de trinta mil almas se ocupão humas em catar, outras em mandar catar nos ribeiros do ouro: e outras em negociar, vivendo e comprando o que se há de mister não só para a vida, mas para o regalo, mais que nos portos de mar" (36).

Pandiá Calógeras estudando essa situação de pânico, assim se manifesta: "Desorganizou-se a cultura das terras, e era isso ameaçador prenúncio, pois poderia valer por um sintoma precursor de nova crise de gêneros alimentícios. Em vão ordenavam os governos locais, os capitães-generais, se fechassem ą estradas e se enviassem patrulhas em perseguição dos fugitivos, ou impunham taxas e multas sôbre tais emigrações. Nada conseguiam as medidas repressivas. As cintilações do ouro e do diamante provocavam tentação irresistivel” (37).

(36) Antonil, Cultura e Opulência do Brasil, pảg. 213.

(37) Pandiá Calógeras, Formação Histórica do Brasil, Coleção Brasiliana, Companhia Editôra Nacional, São Paulo, 1945, pág. 51. 
Em carta dirigida ao Governador da Bahia, em 5 de Maio de 1704, D. Álvaro da Silveira Albuquerque, assim se expressa: "... Em cada dia me acho mais só, assim de soldados como de moradores, porque o excesso com que fogem para as minas nos dá a entender que brevemente ficaremos sem ninguém. Também suponho que V. S. assim o experimenta porque das minas me escreve o Cônego Gaspar Ribeiro que é tanto o excesso de gente que entra pelo sertão da Bahia que brevemente entende se despovoará essa terra." (38).

Boa parcela de culpa pela crise agricola então desencadeada, coube à metrópole, pois com o objetivo de aumentar a produção do ouro e, com isso, auferir mais "quintos", ordenou o fechamento das fábricas das capitanias minerais. "Engenhos, fazendas de tabaco, e semelhantes - diz Pandiá Calógeras - foram proibidos. Assim se originou o grave perigo de tudo fazer depender do metal nobre e das gemas, esquecidos os governos de que, se a faina mineradora viesse a sofrer crise, seria a ruína da colônia" (39).

Para resolver a situação, o Governador do Rio de Janeiro, LuIz Monteiro propôs ao Govêrno de Portugal o monopólio das minas. Acolhendo essas e outras sugestões, tôdas com o objetivo de pôr paradeiro à corrida desenfreada para as minas, a Côrte, que antes incentivara o povoamento das Gerais, acabou por dificultar a ida de novos emigrantes para aquela região. Varias leis foram feitas nesse sentido. Eram, entretanto, desobedecidas e mesmo ignoradas. Nada conseguiu sustar a marcha para as jazidas auriferas, do que resultou um aumento vertigi-

(38) Apud Mafalda P. Zemella, "O Abastecimento da Capitanid das Minas Gerais", tese, Edição da Faculdade de Filosofia, Giências e Letras da Universidade de São Paulo, São Paulo, 1951, pág. 40.

(39) Pandiá Calógeras, ob. cit., pág. 51. 
noso nos arraiais mineiros, que em breve, passaram à categoria de vila.

15 - O ciclo do ouro no Brasil influiu decisivamente tanto na vida da colônia e no fastígio da metrópole, como também na economia mundial. A tal ponto chegou sua influência, que Ellis Júnior, Simonsen e outros atribuem ao ouro brasileiro a causa soberana da Revolução Industrial na Inglaterra, bem como de sua conseqüência imediata, a Revolução Francêsa.

Sigamos o raciocínio dêsses renomados historiadores e sociológos.

Pelo Tratado de Methuen, celebrado em 1703, u precioso metal proveniente das jazidas brasileiras foi levado para a Inglaterra, em apreciável quantidade. Esta, recebendo a avalanche de ouro, se mecanizou. A mecanização, como tinha que ser, diminuiu a mão de obra, mas abriu novos mercados consumidores. $O$ aumento do consumo, resultou na multiplicação das fábricas existentes, absorvendo a mão de obra excedente. A mecanização industrial ocasionou grande aumento nas populações urbanas, aparecendo então as grandes cidades inglêsas.

$O$ desenvolvimento espantoso das indústrias britânicas fêz diminuir o preço dos produtos manufaturados, matando a concorrência de outros países europeus, nesse campo, e ocasionando o colapso da indústria francêsa. Estando econômîcamente forte a Inglaterra, a revolução teria fatalmente que eclodir na França, onde campeava a a miséria e o descontentamento.

Com êsse raciocínio, concluem aquêles autores que o ouro brasileiro foi a causa mestra da Revolução Francêsa, através da Revolução Industrial operada na Inglaterra, afirmando ainda, que o trabalho dos filósofos concorreu com parcela diminuta para a realização daquele movimento político-social na França.

Essa explicação, de caráter ainda controvertido, constitui uma das influências mais sensiveis das avalanches 
do ouro brasileiro, durante o século XVIII, na economia mundial.

Outras conseqüências também se fizeram sentir.

16 - As descobertas das pedras preciosas e do ouro, o impôsto que passou a incidir sôbre essas riquezas, o mecanismo dessa tributação complicado e variável, constituem a trama, que agitaria as terras das Gerais, outrora pacificas e abandonadas.

Discutem os autores a respeito das vantagens advindas de tal situação. Há historiadores que consideram prejudiciais ao progresso da terra a descoberta dos tesouros, pôsto que atrairam, para aquelas bandas, aventureiros de tôda espécie. Southey, por exemplo, é incisivo: "nenehum melhoramento moral trouxe consigo, nenhum aumento de felicidade, podendo entrar em dúvida se promoveu ou retardou ela o progresso da colônia" (40).

Rосна Pомво pensa de maneira oposta: "Apreciando um pouco mais de longe os fatos, e as conseqüências que tiveram em acontecimentos de valor capital na vida da colônia, é preciso admitir e reconhecer que a exploração das minas tem na história do Brasil a importância de fator de primeira ordem" (41).

Parece-nos que os dois citados autores têm sua parcela de razão. $O$ movimento minerador se foi útil de um lado, foi pernicioso de outro. Se trouxe o enriquecimento de uma região, ocasionou também a miséria e o abandono de outras. Já salientámos, páginas atrás, o que foi o êxodo das populações agrícolas para as terras das minas. Só a agricultura pode no Brasil construir pacificamente $\mathrm{e}$ fixar o homem na terra. A mineração o prende pela avidez e temporàriamente. Foi êsse o lado mau do chamado ciclo do ouro.

(40) Southey, História do Brasil, Vol. 5, pág. 52.

(41) Rocha Pombo, História do Brasil, Vol. 6, pág. 171. 


\section{O objetivo econômico da bandeira}

17 - O bandeirismo produziu resultados imprevisíveis. Embrenhando-se pelo sertão em busca do índio, do ouro e das gemas, realizaram os paulistas feitos extraordinários, que lhes conquistaram a posição de destaque que ocupam em nossa história.

Quais foram as conseqüências do bandeirismo? "Tendo por base física as águas, ainda que encaichoeiradas, dos grandes rios, - diz Gilberto Freyre - prolongou-se no brasileiro a tendência colonial do português de derramar-se em vez de condensar-se. O bandeirante, particularmente, torna-se desde os fins do século 16 um fundador de subcolônias. Ainda não é dono da terra em que nasceu, mas um simples colonial e já se faz de senhor das alheias num imperialismo que tanto tem de ousado quanto de precoce. Com o bandeirismo o Brasil autocolonizou-se. Já Pedro Dantas fixou essa possivel constante da nossa história: derramamo-nos em superfície antes de nos desenvolvermos em densidade e profundidade" (42).

Ellis Júnior assim esquematiza a soma de frutos colhidos pelos destemidos habitantes do planalto piratiningano:

a) Alargamento das fronteiras luso-americana-brasileiras, com a expulsão dos espanhóis de grande parte da América do Sul;

b) Criação e manutenção de uma fonte de renda aos planaltinos;

c) Despovoamento do índio e povoamento do europeu em largas extensões da Amẻrica;

d) Mestiçagem intensa entre índios e europeus, no sentido de americanizar a gente planaltina;

e) Devassamento dos territórios sul-americanos;

f) Enriquecimento dos mineradores de Portugal e da Inglaterra, pelo tratado de Methuen, o qual promoveu a

(42) Gilberto Freyre, ob. cit., pág. 78. 
era da máquina, com a ruína da indústria francêsa e a Revolução Francêsa;

g) Perda da independência de fato do planalto;

h) Povoamento do Brasil, pela atração da imigração em massa; e

i) Fornecimento de braços à lavoura de açúcar do Nordeste" (43).

Mas eram êsses os objetivos das bandeiras? Não, evidentemente. Também não foi por simples espírito de aventuras que os paulistas se meteram pelos sertões. 0 objetivo das bandeiras, não padece dúvida, era de natureza econômica. Sua finalidade assentava-se no comércio da carne humana, do ouro e das pedras preciosas. o aspecto mercantil que devemos encarar o objetivo dêsse gigantesco movimento.

Nas páginas anteriores, vimos no estudo dos dois grandes ciclos do bandeirismo, que êle teve duas fôrças a impulsioná-lo: o apresamento do índio, como necessidade imperiosa de uma fonte de riqueza, e a pesquisa mineralógica, para substituir o comércio do índio, quando êste entrou em declínio. Ésses estudos nos forneceram elementos suficientes para concluirmos pela finalidade econômica da bandeira.

Este ponto é pacifico entre os autores. Afonso Arinos de Mello Franco assim se manifesta a propósito: "A bandeira era apenas um instrumento de que a sociedade organizada se servia, a fim de ampliar o campo de seu potencial econômico" (44).

Alfredo Ellis Júnior é taxativo: "É preciso que se compreenda que o bandeirismo não foi como o vulgo ignorante pensa, uma epopéia aventurosa, mas um ciclo econômico tangido pelas circunstâncias imperiosas das

(43) AlfRedo Ellis Júnion, art. cit., in "Curso de Bandeirologia”, pág. 73.

(44) Afonso Arinos de Mello Franco, A Sociedade Bandeirante das Minas, in Curso de Bandeirologia, pág. 82. 
necessidades vitais. Os planaltinos, homens como os demais, colocados em face de certas circunstâncias, foram obrigados a lançar mão do bandeirismo para resolver o seu "primo vivere" (45).

Calógeras, por sua vez, assim se manifesta: "Saída única para tais dificuldades deveria ser arrancar, por quaisquer meios, trabalhadores baratos do viveiro inesgotável da população regional. A escravidão surgiu de tal necessidade econômica" (46).

TAUNAY, o grande historiador das bandeiras, ao estudar o ciclo da caça ao índio, assevera "Assim a primeira fase da devassa do solo brasileiro é o da caça ao índio, nascida de um determinismo econômico" (47).

Finalmente, citemos a opinião de Jonquim Ribeiro, exposta no Curso de Bandeirologia: "Cabe, portanto, ao fator econômico a explicação da origem histórica das cidades na zona do bandeirismo" (48).

As vozes mais autorizadas são unânimes em proclamarem de natureza econômica o objetivo das bandeiras. Sem sofrerem em larga escala a influência do sangue semita, como já tentámos demonstrar, os bandeirantes igualaram ou suplantaram os judeus que, já nos primeiros anos da colonização do Brasil, dominavam o comércio da colônia. E o fizeram de tal maneira que puderam, pelo seu destemor e bravura, construir o Brasil de hoje.

\section{A natureza jurídica da bandeira}

18 - Verificado ser econômico o objetivo da bandeira, tratemos, agora, de fixar sua natureza jurídica.

(45) Alfredo Ellis Júnuor, Meio Século de Bandeirismo, pág. 99.

(46) Pandiá Calógeras, ob. cit., pág. 26.

(47) Afronso E. Taunay, História das Bandeiras Paulistas, Tomo I, pág. 19.

(48) Jonquim Ribeiro, Problemas Fundamentais do Folklore dos Bandeirantes, in Curso de Bandeirologia, pág. 120. 
Do exposto nas páginas anteriores, podemos concluir, sem muita dificuldade, que a bandeira era uma emprêsa em sua forma associativa. Era uma sociedade que se constituia para a realização dos objetivos econômicos já discutidos: o comércio de carne humana, de ouro e pedras preciosas.

Dai resulta que o bandeirante, o chefe sertanista, o "armador" da bandeira, era no fundo um comerciante, pois esta é a qualidade do chefe da emprêsa, quer seja individual, ou uma sociedade. "A emprêsa - diz o Prof. Waldemar Ferreira - constitui, atualmente, o verdadeiro critério da comercialidade". E acrescenta: "O direito comercial deve ser o das emprêsas. Essa noção o unifica. Restitui-lhe seu caráter profissional, sem que se regresse ao direito de casta e de formalismo antigo. Ligam-se-lhe as noções de atos de comércio e de comerciante" (49).

19 - Mas o que é uma emprêsa? Para o grande comercialista J. X. Carvalho de Mrndonça "emprêsa é a organização técnico-econômica que se propôe a produzir, mediante a combinação dos diversos elementos, natureza, trabalho e capital, bens ou serviços destinados à troca (venda), com esperança de realizar lucros, correndo os riscos por conta do empresário, isto é, daquele que reúne, coordena e dirige êsses elementos sob a sua responsabilidade" (50). E esclarece que êsse conceito é o econômico e também o jurídico, acrescentando: "O direito comercial considera a emprêsa que se apresenta com caráter mercantil. Dêsse modo o empresário, organizando e dirigindo a emprêsa, realiza, como todo o comerciante, uma função de mediação, intrometendo-se entre a massa de energia

(49) Waldemar Ferreira, Instituições de Direito Comercial, Vol. I, Livraria Editôra Freitas Bastos, 1944, Rio-São Paulo, págs. 104 e 105.

(50) José Xavier Carvalho de Mendonich, Tratado de Direito Comercial Brasileiro, Vol. I, 3a Edição, Livraria Editôra Freitas Bastos, 1937, no 345, pág. 492. 
produtora (máquinas, operários, capitais) e os que consomem, concorrendo destarte para a circulação da riqueza" (51).

Vejamos se a bandeira se enquadra dentro do conceito de emprêsa proposto por $J$. X. Carvalho de Mendonça, analisando todos os seus aspectos:

a) "uma organização técnico-econômica":

A emprêsa pode ser uma organização individual ou coletiva, isto é, pode ser exercida por pessoa natural ou pessoa jurídica. Deve ser técnico-econômica. A técnica é o conjunto de conhecimentos que torna o homem capaz de atuar sôbre o mundo que o rodeia. Sua perfeição consiste tão sòmente no objeto produzido ou no serviço prestado. $O$ fator técnico não se confunde com o fator econômico. O grau de perfeição mede-se entre o que foi empregado e o que foi obtido. Embora não se confundam, os fatôres técnicos e econômicos estão sempre jungidos um ao outro, pois ambos se completam na tarefa da produção.

Acho que podemos perfeitamente falar em uma "técnica bandeirante", da mesma forma que os autores falam em um "tipo bandeirante", em uma "raça bandeirante" Sòmente o homem do planalto conhecia tôdas as particularidades da organização e execução dessas expedições ao sertão. Isso ficou demonstrado, quando cuidámos da bandeira como "fenômeno tipicamente paulista" e do desejo ostensivo da metrópole em entregar aos paulistas a tarefa de constituirem e dirigirem as bandeiras mineradoras.

Quanto ao fator econômico, o conjunto dos meios proporcionados para a realização de sua finalidade já estudada, constituiu-se num dos elementos mais precários dessa emprêsa. Já analisámos a pobreza dos vicentinos, quando cuidámos do preamento de índios. Tudo era difícil. "Tamanha é a escassez de numerário - afirma Alcântara MACHADO - que os colonos voltam ao sistema prehistórico dos

(51) José Xavief Carvalho de Mendonça, ob. cit., pảgs. 492 e 493. 
escambos in natura, dos pagamentos em espécie. Não só os colonos. A própria municipalidade paulopolitana tem de passar pelo vexame de satisfazer "em palha" o salário do porteiro do Conselho" (52). Mas o bandeirante, no mais das vêzes, soube resolver o problema econômico da empreitada, permitindo que esta atingisse a finalidade proposta. Ao estudarmos o elemento "capital", como fator de produção, voltaremos ao assunto.

b) "que se propõe a produzir, mediante a combinação dos diversos elementos, natureza, trabalho e capital".

Para que a emprêsa possa conseguir os seus objetivos, isto é, produzir, é necessário que ela conjuge os fatôres da produção. Êstes, de acôrdo com o ensino clássico, são a natureza, o trabalho e o capital. Nos dias que correm, uns incluem o Estado entre êsses fatôres; outros, a técnica; e outros ainda, a organização.

A natureza se apresenta nesse conjunto, através da situação geográfica, clima, fontes de energia, matérias primas, etc. $O$ trabalho é a aplicação da atividade humana a fim econômico. É, assim, a própria atividade econômica. O capital é o traço de união entre o homem e o mundo exterior, pois os bens e serviços resultam do trabalho aplicado à natureza. Instalações, instrumentos, matérias primas, provisões, etc., são categorias dêsse elemento. Modernamente, com o uso da moeda, que reduz tudo isso a uma categoria só, é costume exprimir-se o capital por uma soma de dinheiro.

Vejamos os três fatôres da produção dentro da bandeira:

1) Natureza. O ambiente onde se desenvolveu o bandeirismo foi o mais desfavorável possível. Rica em animais, frutas, minerais, rios e cachoeiras; habitada por uma população mergulhada em pleno periodo neolítico e que alcançava apenas o estado fetichista; repleta de serras e outros acidentes difíceis de serem vencidos, a natureza do

(52) Alcântara Machado, ob. cit., pág. 134. 
Brasil representou fator preponderante na glória alcançada pelos bravos homens de São Vicente.

Produto da ecologia do planalto, para a qual, em segundo plano, convergiram fatôres raciais e histórico-sociais, conforme já salientámos, o bandeirante teria também no meio físico um elemento decisivo na sua obra.

0 sertão foi sempre um atrativo para o piratiningano. Diz bem Alcântara Machado: "O sertão foi o centro solar do mundo colonial. Gravitam-lhe em tôrno, escravizados à sua influência e vivendo de sua luz e de seu calor, todos os interesses e aspirações" (53).

2) Trabalho. Na organização das bandeiras aparece em primeiro plano, o mameluco. 0 próprio chefe da expedição, o sertanista, era no mais das vêzes, um mameluco. Em plano inferior, aparecem o índio, o negro, além de alguns outros elementos alienígenas, movidos pela cobiça ou desejo de aventuras. Sôbre o bandeirante-mameluco já falámos em outro capítulo.

Quanto ao trabalho na bandeira, o índio foi excelente. Se sua contribuição para a lavoura e a indústria da colônia foi fraca, como já vimos, "sua contribuição foi notável na obra de devassamento e de conquista dos sertões, de que êle foi o guia, o canoeiro, o guerreiro, o caçador e pescador. Muito auxiliou o índio ao bandeirante mameluco, os dois excedendo ao português em mobilidade, atrevimento e ardor guerreiro", salienta GILberto Freyre" (54).

0 índio foi assim um co-autor de sua própria conquista.

Os autores, na sua maioria, fazem referências ao trabalho do negro nas bandeiras. EuLIS JúrNion, entretanto, nega a participação do africano no bandeirismo. Em trabalho apresentado ao III Congresso Sul-Riograndense de História e Geografia, e intitulado O Negro no Bandeirismo, defende o seu ponto de vista, que em resumo é o seguinte

(53) Alcântara Machado, ob. cit., pág. 244.

(54) Gilberto Freyre, ob. cit., pág. 221. 
(55): O negro é inferior ao branco em muitos aspectos e superior em outros, pois na verdade, não há raças inferiores e superiores, mas sim raças desiguais. Os negros vieram ao Brasil pela primeira vez em 1548. Nos documentos antigos, como uma carta de NóBregA, a palavra "negro" não se referia aos africanos, e sim, aos "ameríndios", que eram designados indiferentemente como "gentíos" ou "negros". Quando queriam designar o africano, faziam-no chamando-os de "tapanhunos" ou de "negros da Guiné", ou de "gentíos da Guiné". Nem será de interpretar de modo contrário, pois as cartas de Nóbrega ao Padre Simão RoDrigues, datam de 1549, quando é certo que os primeiros africanos haviam chegado em 1548, com ToMÉ de Sousa. Não havia tempo para os primeiros africanos merecerem as referências. Por isso, o negro não influiu no bandeirismo, embora Afonso Sardinha tivesse empregado africanos em sua mineração. O cálculo censitário da Enformações, referente ao ano de 1583 não acusa a presença de africanos em S. Vicente e sim 1.500 brancos e 1.000 índios. Dos cronistas da Companhia de Jesus, que se referem ao bandeirismo, nenhum fala em africano na componência das bandeiras. Todos os autores que cuidam do bandeirismo não se referem à presença do africano. Até 1583 não havia pretos em São Paulo.

Essa a opinião do insígne Alfredo Ellis Júnior a respeito da participação do negro na bandeira.

Cassiano Ricardo, entre outros, diverge do mestre paulista. Em sua Marcha para Oeste e no Volume n. ${ }^{\circ} 47$ da Revista do Arquivo Municipal, de S. Paulo, em artigo intitulado, $O$ Negro no bandeirismo paulista, expõe idéias a respeito.

Diz êle que o negro participou ativamente do bandeirismo, especialmente no ciclo da mineração. "Há -

(55) Alfredo Ellis Júnion, $O$ Negro no Bandeirismo, in Anais do III Congresso Riograndense de História e Geográfia, $3^{\circ}$ Volume, Pôrto Alegre, 1940, pág. 1571. 
afirma Cassiano Ricardo - um ponto pacífico em bandeirologia, e que vem a propósito: cada bandeira não mais era do que um prolongamento do planalto. Se havia negro no planalto, havia negro na bandeira. Quantas vêzes ocorre o fato de ficar a vila deserta por os moradores terem ido ao sertão. Não teriam os negros, evidentemente, feito exceção a essa regra, ficando em casa quando todos seguiam sertão a dentro. Francamente, a lógica está gritando e dizendo que os negros existentes no planalto iam todos na tropa" (56). E dá alguns detalhes. Os primeiros negros de serra acima que participaram das bandeiras foram os de Afonso Sardinha. Outros participaram da grande bandeira de Fernão Dias Pais. Pascoal Moreira também levou consigo boa coleção de tapanhunos, e na bandeira do segundo Anhangüera, de 1722, seguia também grande quantidade de negros.

Achamos que a razão está com Cassiano Ricardo. Contràriamente à tese defendida por ELLIS JúnIOR têm opinado vários estudiosos do assunto. Alcântara Machado e Taunay estão entre êles.

O negro participou do bandeirismo. É o que se deduz dos documentos oficiais. Enquanto em marcha, a bandeira utilizou mais o trabalho do índio; quando acampada, para abastecimento e descanso, valeu-se principalmente do negro. Isso se explica pelo nomadismo inato do selvagem, em contraste com a tendência sedentária do negro.

Taunay fala mesmo em uma bandeira organizada pelo padre João Álvares, na primeira metade do século XVII, da qual não fazia parte um só branco: era constituida exclusivamente de índios e negros. E cita "a coexistência freqüente nas mesmas mesnadas de índios e tapanhu-

(56) Cassiano Ricardo, ob. cit., Tomo II, pág. 21. 
nos recém vindos do além Atlântico, sobretudo depois de passadas as primeiras décadas da colonização" (57).

A ação do escravo africano se fez sentir mais intensamente no bandeirismo, durante o ciclo da mineração, quando então o braço indígena foi substituido pelo africano, ocasionando séria crise no abastecimento da colônia, conforme já salientámos no estudo que fizemos sôbre o ciclo do ouro.

O trabalho na bandeira baseou-se, principalmente, na escravidão. Foi o trabalho escravo do índio e do negro que impulsionou o bandeirismo.

Como se portavam os paulistas diante da legislação da metrópole que proibia a redução do selvícola ao cativeiro? Para que os colonos e também os bandeirantes pudessem, mediante registro na provedoria, legitimar a posse sôbre os "indios descidos", criou-se um estado intermediário entre a escravidão e a liberdade: o "serviço fôrro". "A êle se alude pela primeira vez - diz Alcântara Machado em 1603 no testamento do sertanista Manoel de Chaves: “tenho um moço de serviço fôrro. . outro casado. são serviços de obrigação da minha casa". Poucos, a princípio, os índios assim classificados. Mas o número dêles vai crescendo, dia a dia, em progressão vertiginosa, ao passo que vai minguando paralelamente o dos escravos. Antes de iniciado o segundo quartel do século XVII a escamoteação está consumada. Somem-se das avaliações os cativos do gentío brasílico, e aparece marcado como "gente fôrra, almas ou gente do Brasil, serviços obrigatórios, peças fôrras serviçais", todo o rebanho humano que apulenta os acervos. Depoís os indígenas oprimidos passam a chamarse "administrados" do inventariado ou "servos de sua administração. Simples mudança de rótulo, sem conseqüências" (58).

(57) Afronso E. Tautnay, História Geral das Bandeiras, Tomo V, Edicão Melhoramentos, São Paulo, pág. 107.

(58) Alcântara Machado, ob. cit., pág. 168. 
Explica ainda o autor de Vida e Morte do Bandeirante que o "serviço pessoal" de que acabámos de cuidar, os paulistas o conheceram através dos colonizadores espanhóis. Estes instituiram dois regimes de trabalho. Um, pelo qual os indios eram obrigados a servir os colonos, percebendo salário durante um espaço de tempo prefixado. $O$ outro, submetia os índios, perpétua e gratuitamente, aos colonos para os trabalhos agrícolas e domésticos.

Adotando essas práticas dos espanhóis, os paulistas burlavam as leis portuguêsas que vedavam o constrangimento do índio ao serviço, invocando "o fôrro e o costume", ou "estilo da terra", ou que agiam "na conformidade que os mais moradores desta Vila o faziam" e de acôrdo com a "justiça ordinária".

Com as Cartas Régias de 26 de Janeiro e 19 de Fevereiro de 1696 , essa situação legalizou-se, pois foi concedida aos cidadãos de S. Paulo, bem como aos seus descendentes, a administração dos gentíos. Êsse regime de tutela foi aos poucos se deturpando, até que acabou por transformar-se em escravidão.

Portanto, foi na mesma posição do negro que o índio participou das bandeiras: reduzido à condição de escravo.

Quanto ao trabalho do bandeirante mesmo, são expressivas as palavras de Cassiano Ricardo: "Vaqueiro, criador de boi, tropeiro, lavrador, industrial, operário, caçador - tudo isso são atividades que o bandeirante exerce, accessòriamente, sem prejuizo de seu principal mister" (59) ;

3) Capital. Havia na bandeira o sócio capitalista. Muitas vêzes era o próprio chefe bandeirante, o "armador, que financiava a empreitada. É o caso da última e grande bandeira de Fernão Dias Pais que, para aquiescer aos desejos da metrópole, teve que desfazer-se de quase todos os seus bens a fim de levar ao sertão a sua gente. "Às vêzes

(59) Cassiano Ricardo, ob. cit., Tomo II, pág. 86. 
- diz o sempre citado Aicântara Machado - é um bandeirante que, mediante a paga combinada de antemão, se encarrega de levar "por ida e vinda" o parceiro, desprovido de meios para enfrentar os gastos de viagem. Prova-o esta "clareza" junto ao inventário de Martim Prado: "Digo eu. que me concerto com Felipe de Veres o levar a esta jornada em minha companhia nesta entrada adonde vai LAzARo da Costa, o qual me obrigo a levar por ida e vinda, dando-me Nosso Senhor vida e saúde, por preço e quantia de dez mil réis em dinheiro, de contado ou em fazenda. Donde se conclui que o sertanista custeava a excursão, emitindo bilhetes de ida e volta, "tout compris" $(60)$.

Referindo-se à bandeira de Anhangüera, Domingos do Prado e João Leite da Silva Ortiz, diz Taunay, valendo-se de Pedro Taques: "Hesitou, porém, em comprometer a situação brilhante que alcançara, em suas ricas lavras do Rio das Velhas, e só o fêz a "persuasões do seu irmão" Fazendo vender por um o que valia dez, se recolheu a S. Paulo, onde à custa dos seus grandes cabedais, se formou o trôço de quinhentos homens, em cujo corpo penetrou o inculto sertão de Goiás, sofrendo no decurso de três anos e oito mêses perdas, trabalhos e misérias sem conta", escreveu o seu sobrinho, autor da Nobiliarquia Paulistana. E acrescenta: "Era, pois, o capitalista da emprêsa como hoje se diria" (61).

De que se constituia o capital dessa emprêsa? De escravos, armas, munições de guerras, mantimentos, correntes, tachos, cuias, roupas, etc. Enfim, tôda uma série de coisas, algumas bem curiosas e estranhas, que seria longo enumerálas. Tôda a importância disponível era empregada no aviamento da bandeira. De que valia o dinheiro no sertão? Das armas, a mais utilizada era a "escopeta", que Bluteau,

(60) Alcântara Machado, ob. cit., pág. 251.

(61) Affonso E. TAunay, História das Bandeiras Paulistas, Tomo II, pág. 189. 
citado por BeLmonte, diz ser mais curta e de menor bala que a espingarda e a pistola" (62). Aparecem também a clavina, o alcabuz, o bacamarte, a espingarda e a pistola. Quando à roupa, afirma Alcântara Machado que o "bandeirante levava no corpo quase todo o seu fato: chapéu pardo roçado, ou carapuça, ou lenço e pano de cabeça; meias de cabrestilho ou cabresto; sapatos de vaca, veado, carneiro, cordovão ou vaqueta; ceroulas e camisas de algodão; roupeta e calções de baeta ou picote" (63).

O preparo da expedição era longo e o seu custo bem variado. Alcântara Machado e Taunay referem-se às somas de dinheiro empregadas em algumas bandeiras. Assim, a de José Pompeo, filho de Lourenço Taques, custou 20\$000; a de Francisco Dias da Silva, sobrinho de Fernão Dias Pais, importou em 26\$500; e a do capitão Antônio Pais, em 107\$984. Sôbre esta última, Taunay narra o seguinte: "emprestou-lhe Manuel da Fonseca Osório : .. 107\$984 "para o seu aviamento de pólvora, chumbo, espingardas e outras coisas". Era a emprêsa aleatória e a jornada longuíssima. Assim o armador prometia ao seu credor "a terça parte das peças que Deus fosse servido dar-lhe com suas familias". Isto atẻ sessenta peças. Com a entrega destes sessenta indios saldar-se-ía o compromisso aliás garantido pela hipoteca de duas casas. $E$ sendo que Deus "dêle dispusesse no sertão, ficaria a viúva responsável pela dívida” (64).

Os gastos eram enormes e a ajuda oficial era nula. As promessas de "mercê e graças" reiteradamente feitas pelo rei a algumas expedições ficavam apenas em promessas. Disso resulta ser da maior importância a presença do sócio capitalista. Este nem sempre acompanhava a bandeira. Ficava, muitas vêzes, na retaguarda, na base,

(62) BeLmonte, ob. cit., pág. 242.

(63) Alcântara Machado, ob. cit., pág. 252.

(64) Afronso E. Taunay, História Geral das Bandeiras, Tomo V, págs. 92-93. 
cuidando do envio periódico de suprimentos à tropa em ação. Houve figuras que se celebrizaram no financiamento de bandeiras sem que, entretanto, as acompanhassem em suas caminhadas pelo sertão. Entre elas citam os autores o Padre Pompeu de Almeida. Sôbre êle afirma Cassiano RICARDo: "Financiava muitas expedições das quais se fêz sócio capitalista. Alguns historiadores o apontam mesmo como um incansável organizador de mantimentos e boiadas com que, mesmo depois de partirem as bandeiras, ficavam atendendo às necessidades da tropa" (65);

d) "produzir bens ou serviços destinados à troca (venda) com a esperança de realizar lucros".

O produto é resultado da combinação dos três fatôres já estudados. Bens são os produtos materiais e serviços, os imateriais. 0 produto se destina à troca, e não ao uso próprio da emprêsa. Ex mercadoria que se vende, isto é, que se troca mediante moeda e crédito. Visa a satisfação das necessidades de uma outra entidade, do que lhe advirá o lucro ou proveito. $O$ lucro é a diferença entre o custo de produção e o preço de venda. Depende essencialmente de ambos, que são as suas causas.

$\mathrm{Na}$ bandeira os três fatôres da produção se associaram no sentido de obter, em sua primeira fase, um produto bastante cobiçado: o índio. Êste produto, de acôrdo com o raciocínio exposto acima, era trocado, era vendido. Visava a satisfação das necessidades de mão de obra nas lavouras e engenhos do Nordeste, principalmente. Em segundo plano, destinava-se a servir a outros setores da colônia, bem como à exportação. Em sua segunda fase, no ciclo da mineração, tinha em mira outro produto: o ouro e as pedras preciosas. Os aspectos gerais dêsses dois ciclos já foram por nós verificados, páginas atrás.

Vemos, portanto, que a bandeira era uma emprêsa que se propunha a produzir "bens". Mas o que é um "bem"?

(65) Ciassiano Ricardo, ob. cit., Tomo I, pág. 256, nota 27. 
"Bem - diz Clóvis BeviláQua - na linguagem filosófica, é tudo quanto corresponde à solicitação dos nossos .desejos. Para a economia política, bem é aquilo que concorre para satisfazer uma necessidade humana. Para o direito, o "bem" é uma utilidade, porém com a extensão maior do que a utilidade econômica, porque a economia gira dentro de um círculo determinado por êstes três pontos: o trabalho, a terra e o valor; ao passo que o direito tem por objeto interêsses, que se realizam dentro dêsse círculo, e interesses outros, tanto do indivíduo quanto da família e da sociedade. Assim, no direito há bens econômicos e bens que o não são. Os bens econômicos formam o nosso "patrimônio" (66).

A bandeira visava a produção de bens econômicos: as "peças" (como eram designados os índios "descidos"), o ouro e as gemas. O índio reduzido à escravidão, apesar das proibições legais, era um "bem econômico", pois de acôrdo com o Direito Romano, em que se baseara o Direito Português vigente na colônia, os escravos eram "coisas", "res se moventes", da mesma maneira que os animais. Os escravos, animais ou instrumentos eram "instrumentum fundi", podendo ser objeto de compra e venda.

Ora, sendo o escravo considerado "coisa", era também um "bem", porque, explica CLóvis BeviLÁQUa: "Embora o vocábulo "coisa" seja no domínio do direito, tomado em sentido mais ou menos amplo, podemos afirmar que designa, mais particularmente, os "bens" que são, ou podem ser, objeto de direitos reais. Neste sentido dizemos "direito das coisas" (67).

Os bens, os produtos das bandeiras, destinavam-se à venda, conforme já vimos, e eram repartidos entre os membros da expedição, de acôrdo com o que fôra estipulado no contrato de constituição da sociedade. Mas, geral-

(66) Clóvis Beviláqua, Teoria Geral do Direito Civil, 2a Edição, Livraria Francisco Alves, Rio, 1929, pág. 208.

(67) Clóvis Beviláqua, ob. cit., pág. 208. 
mente os lucros eram repartidos pela metade entre o chefe da expedição e o sócio capitalista. No testamento de Antônıo Ribeiro há o seguinte: "Dei de armação para o sertão dois negros e uma escopeta e seis libras de pólvora e doze de munição e o mais necessário que há mister, com partido de que, trazendo remédio, partir a metade comigo" (68). Contratos diferentes também eram feitos. Financiando a bandeira de Antônio Pais, diz Manuel da Fonseca Osório: "sob a condição de trazendo-o Deus do sertão e ao dito senhor seu filho, entregar ao capitalista a terça parte das peças que Deus fôr servido dar-lhe com suas famílias, e, sendo caso que não traga peças, pagar o débito depois da chegada a um mês, sem a isso por dúvida alguma" (69). Na bandeira de Jerônimo Camargo e AnTônio BuEno, o seu capelão perceberia a metade das 100 primeiras "peças" capturadas.

Raramente aparecia quem desse escravos, armas e munições "de amor em graça, desinteressadamente, a um parente necessitado, a fim de ajudá-lo a buscar a vida";

e) "correndo os riscos por conta do empresário, isto é, daquele que reúne, cordena e dirige êsses elementos sob a sua responsabilidade".

Para obter-se lucro é necessário que o preço da venda, como é óbvio, seja superior ao custo da produção. Todavia, isso nem sempre se dá, ocorrendo às vêzes, prejuízos. E a emprêsa, que é uma organização que produz para vender e ganhar, traz inerente ao seu conceito o "risco econômico", distinto do "risco técnico" - imperfeição ou deterioração do produto -, ainda que bastante ligado a êste. Cabe ao empresário arcar com os riscos, devendo para obstá-los, ser o mais expedito possivel na harmonização e coordenação dos fatôres de produção.

A bandeira estava também sujeita aos seus riscos. Do risco econômico, principalmente. Muitos bandeirantes fra-

(68) Alcântara Machado, ob. cit., pág. 250.

(69) Alcântara Machado, ob. cit., pág. 250. 
cassavam na jornada, regressando quase de "mãos vazias"; outros sofrendo ataques dos gentios viam também sua emprêsa malograda. No primeiro caso está a bandeira de ANDRÉ LEÃo, uma das primeiras a ser armada na fase da mineração, que, partindo em 1601, depois de custoso aviamento, regressava no ano seguinte sem nada descobrir. No segundo caso, podemos citar a desastrada bandeira de Pascoal Leite Pais, irmão de Fernão Dias Pais, que partindo em busca de gentíos das "reduções" jesuíticas, foi arrazada, em Caasapaguaçu, pelos inacianos e índios.

Em outras ocasiões, era o próprio chefe sertanista que perecia no sertão, deixando sua expedição reduzida ao fracasso. "Morto no sertão - diz Paulo Prado - é o sinistro estribilho dos inventários daquela época" (70). E Alcântara Machado acrescenta: "Para o capitalista o negócio é bem aleatório. Pode suceder, e sucede a meúde, que o aventureiro "faleça da vida presente" na jornada, ou venha perdido, como aquêle armador, de que fala um dos inventários, que deixou no sertão seis negros dos doze que levara, e mais a negra e a corrente. Orça por trinta mil cruzados o prejuizo do capitão-mór Pedro Taques DE Almeida, que os adeantou, na expressão do genealogista homônimo, sem mais segurança que o conceito que lhe merecia a verdade dos devedores" (71).

$O$ risco técnico também se fazia presente. $O$ produto nem sempre estava em condições de satisfazer ao mercado. Muitas vêzes as "peças" chegavam em precárias condições, devido, principalmente, às doenças, muitas das quais adquiridas dos brancos, conforme salientam vários autores, ou então, em razão dos sofrimentos do próprio cativeiro. As "correntes" eram responsáveis por muitas das "peças" perdidas ou desgastadas. Em outros casos, regressavam com pedras sem valor, na ilusão de que haviam conseguido um produto à altura dos desejos da metrópole e dos sacri-

(70) Paulo Prado, ob. cit., pág. 265.

(71) Alcântara Machado, ob. cit., págs. 250 e 251. 
fícios da expedição. E o que aconteceu com as "turmalinas" da famosa Bandeira das Esmeraldas de Fernão Dias PaIS.

Correndo por sua conta os riscos da emprêsa, o bandeirante, isto é, "aquêle que reúne, cordena e dirige êsses elementos sob a sua responsabilidade", tinha que revelar qualidades sobejas de administrador, de chefe, para o bom êxito de sua autoridade sôbre tôda a bandeira em marcha.

$\mathrm{E}$ foi visando justamente a posição do bandeirante como "empresário" que, no Capítulo I, n. ${ }^{\circ} 5$, cuidámos do assunto. Depois de combatermos, entre outras, a explicação de OuIveIra Viana baseada no latifúndio, aceitámos a posição assumida por JoAquim Ribeiro, que fundamenta as qualidades do sertanista como chefe em dois elementos associados: um europeu, românico, o "pátrio poder" no seu sentido clássico; e outro o aborígene, tribal, "o caciquismo". A propósito, diz êste autor: "O pátrio poder, nos séculos passados, possuia uma função social demasiado ampla. $O$ chefe bandeirante exercia o poder não só sôbre os membros legítimos da família, como ainda sôbre os bastardos, a escravaria e os apaniguados; todos os filhos naturais ou legitimos, escravos ou foreiros, eram considerados "alieni juris". A tradição românica estava em pleno vigor. A essa noção românica de clã parental veio juntar-se o "caciquismo", que a organização tribal sugeria. Na bandeira fundiram-se os dois elementos" (72).

A essas qualidades do bandeirante como chefe, ao seu prestígio na direção da emprêsa, devemos, principalmente, o êxito do bandeirismo, a sua benéfica soma de conseqüências.

20 - Muitos historiadores fazem referências ao caráter mercantil da bandeira, taxando-a de emprêsa em sua forma associativa.

Verifiquemos algumas passagens entre os autores que mais vimos citando.

(72) JoAQuim Ribeirio, ob. cit., págs. 29 e 30 . 
Alcîntara Machado, em sua preciosa obra Vida e Morte do Bandeirante cuida da bandeira como sociedade comercial, referindo-se em vários tópicos ao sócio capitalista, ao aviamento e à divisão dos lucros das expedições. São suas estas palavras, em páginas diferentes dessa obra: “ $O$ capitalista dá ao bandeirante, que toma o nome de armador, o que os documentos da época chamam de armação"; "para o capitalista o negócio é bem aleatório"; e "geralmente os lucros são repartidos pela metade".

Taunay, por sua vez, na História das Bandeiras Paulistas, usa várias vêzes a palavra "emprêsa", embora nem sempre no sentido que the estamos dando. Mas no Volume II, à página 189, diz: “à emprêsa projetada entenderam associar João LeITe dA Silva Ortiz"; e logo adiante: "Muito natural pois que ORTIZ quisesse incorporar-se à emprêsa destinada a tão dadivoso descobrimento em perspectiva... Era, pois, o capitalista da emprêsa como hoje se diria".

Casstano Ricardo é do mesmo pensar. Depois de referir-se, no Volume I da sua Marcha para Oeste, várias vêzes, ao "sócio capitalista", afirma no Volume II do mesmo trabalho: "Organizavam-se sociedades, empreitadas, contratos de vários tipos para a realização de tal propósito. Citam-se casos de combinação entre o índio aldeado que, em troca de uma espingarda, se prontificava a chefiar entradas. Os próprios jesuítas, pondo de parte o seu mister espiritual, fazem seus tratos com os bandeirantes. E quase sempre, ajustes que bem exprimem o espírito associativo, criado pela bandeira, os lucros são repartidos por metade ou proporcionalmente entre o que fornece material para a emprêsa $e$ os que se abalaram sertão a dentro. Verdadeira associação de homens para a luta sertaneja, foi a bandeira o apanágio dos paulistas. . Os lucros dos apresamentos eram conquistados em comum e depois proporcionalmente divididos" (73).

(73) Cassiano Ricardo, ob. cit., Vol. II, págs. 86 e 87. 
O caráter associativo pôsto em prática pelas bandeiras iria refletir, logo mais, na organização das sociedades mineralógicas. "Exemplo dêsse espírito associativo criado pelo ouro - afirma o historiador Nuto Sant'AnNa - é o que nos dá o contrato referente à mineração do Tietê. Os escravos seriam obtidos por conta da sociedade "sem que cada um dos sócios pudesse ter uma só peça mais que outro, de sorte que o ouro que se extraisse seria repartido igualmente" (74).

21 - Como poderíamos situar essa emprêsa entre as sociedades comerciais modernas?

Não sendo constituida mediante contrato escrito, pois o direito vigente na época não o exigia, torna-se assaz difícil o enquadramento da bandeira naquele ról.

Todavia, ela apresenta aspectos de semelhança com algumas emprêsas dos dias atuais.

Num sentido genérico a bandeira pode ser chamada de companhia, pois surge com impulso semelhante às companhias que, no seiscentismo, se organizaram na Holanda, Inglaterra e também Portugal.

Dessas, as holandêsas foram as que se mais destacaram no comércio e navegação. Em 1602, foi constituida a Companhia das Indias Orientais, de caráter permanente, visando o comércio e a navegação com as Índias. "O que os contigentes históricos revelam — afirma o Prof. WALdemar Ferreira - é que, realmente, nasceu a Companhia das Indias Orientais, na Holanda, como o meio mais eficaz para a solução dos problemas que naquele país se apresentaram no momento difícil que ela atravessava, assim interna, como externamente. Resultou ela de concepção original, como derivação do processo da economia medieval, que se baseava na fôrça das cidades, erigidas em co.*

(74) Nuto San'r'anna, São Paulo Histórico, Coleção do Departamento de Cultura, Vol. I, Rossolillo Editor, São Paulo, 1937, pág. 82. 
munas autônomas, embriões dos organismos estatais que ao depois se cristalizariam em nações" (75).

Em 1621, visando o comércio e a navegação nas costas e países da África, bem como nas índias Ocidentais, ou seja, a América, é organizada a Companhia das índias Ocidentais. Esta, embora baseada na primeira, teve objetivos mais amplos.

É nessas companhias - fato que merece real destaque - que deitam suas raizes a atual sociedade anônima. Ê êsse também o pensamento do Prof. Waldemar Ferrira, quando diz: "No estado atual das indagações históricas, ninguém mais duvida de que a moderna sociedade anônima se filia diretamente às companhias holandêsas de comércio e colonização, constituindo o natural desenvolvimento daquelas emprêsas" (76).

Organizada para o comércio e a navegação, todavia, a Companhia das Índias Ocidentais, dedicou-se mais à pirataria e à conquista.

As bandeiras tiveram ímpeto semelhante às companhias holandêsas. Enquanto que as companhias se armavam para a pirataria, as bandeiras se organizavam para o preamento do índio. Ambas eram "associações semi-bélicas" constituidas para fins mercantis, mas tiveram conseqüências políticas; ambas visavam a conquista por meios violentos, mas colonizaram. Há entre as bandeiras e as Companhias Holandêsas das Índias, concluimos, impulsos semelhantes.

Achamos, entretanto, que os pontos de semelhança mais se acentuam, quando comparamos a bandeira com a moderna sociedade de capital e indústria. Essa é também a opinião de Alcântara Machado. Éste autor vê na bandeira "uma verdadeira sociedade de capital e indústria", afirmando: "os dinheirosos entram com o capital e os pobres com o heroismo. No final havia a partilha das peças"

(75) Waldemar Martins Ferreira, História do Direito Brasileiro, Tomo III, Max Limonad Editor, S. Paulo, 1955, pág. 40.

(76) Waldemar Martins Ferreira, ob. cit., pág. 99. 
(77). Era assim a bandeira. Enquanto que o sócio capitalista fornecia todo o aviamento, os outros membros da tropa, representados pelo chefe sertanista, entravam com a indústria, isto é, com o trabalho.

Do estudo que fizemos da bandeira como emprêsa, vemos que ela se ajusta, em termos genéricos, dentro dêste conceito: é sociedade estabelecida "entre pessoas que entram com os fundos necessários para negócios comerciais em geral ou para algum em particular, e as que entram com sua indústria sòmente. Denomina-se de capital $\mathrm{e}$ indústria. Indústria no sentido de trabalho. Tem-se nela a em que todos coparticipam dos lucros e alguns não contribuem para os prejuizos, por não ministrarem, para o capital social, nenhuma quantia em dinheiro, nem bens ou direitos" (78).

$\mathrm{E}$ as monções? Estas também eram emprêsas mercantis. Emprêsas que operavam nos rios, formando comboios que levavam "grande massa de gente, homens, mulheres, crianças, velhos, etc.", para as zonas das lavras, onde se entregavam "à atividade mineradora, mas, também, às correlatas".

De que tipo eram elas? Eram emprêsas de transporte fluvial. Empregando veículos de transportes, os mais variados tipos de embarcações, os paulistas da fase monçoeira exerciam o seu arriscado mister, visando o proveito, o lucro. Foram os pioneiros dos transportes coletivos no Brasil. Hoje, quarido se fala entre nós na regularização dos cursos dos grandes rios para a utilização dos transportes fluviais, a exemplo de outros países, é justo que exaltemos as proezas nunca igualadas dêsses exímios canoeiros. $\mathrm{O}$ capítulo das monções juntou novas glórias à gente vicentina.

(77) Alcântara Machado, ob. cti., pág. 249.

(78) Waldemar Martinis FerReira, Instituições de Direito Comercial, Volume I, 3a Edição, Livraria Freitas Bastos S.A., RioSão Paulo, 1951, págs. 302 e 303 . 


\section{Conclusão}

22 - 0 bandeirismo, fenômeno tìpicamente paulista, constitui episódio fundamental na formação da nacionalidade brasileira. Com êle o Brasil auto-colonizou-se, e, por isso, é marco decisivo em nossa história. "Quando entra no sertão a primeira bandeira, - diz Alberto de Oliverrs - termina a história de Portugal e começa a do Brasil".

o Bandeirante é um produto do planalto paulista. Moldado, principalmente, pelo fator ecológico, sôbre êste convergiram fatôres raciais e histórico-sociais, na complementação de seu quadro formador.

Sua extrema mobilidade é devida ao sangue indigena que participou em sua formação mameluca, e sua autoridade e prestígio como chefe da expedição, ligam-se a dois fatôres conjugados: "o "pátrio poder", no seu sentido clássico, e o "caciquismo".

Foi o objetivo econômico que animou as bandeiras. No ciclo da caça ao índio, em razão da pobreza em que se mergulhara a Capitania de S. Vicente, o paulista lançou-se pelo sertão na perseguição do gentio, visando satisfazer às necessidades de mão de obra nas lavouras e engenhos do Nordeste; e, secundàriamente, fornecer o indio feito escravo a outros setores da colônia e à exportação.

0 segundo cìclo, o da mineração, teve a determiná-lo a crise do açúcar, motivada pela concorrência das Antilhas, que obrigou o paulista a abandonar a indústria de apresamento, e também a cobiça da metrópole.

Nos trabalhos da lavoura e da indústria o negro foi superior ao índio, mas nas tarefas das bandeiras, em que também o negro participou, o índio venceu-o de longe.

Embora animada de objetivo econômico, a bandeira produziu uma soma benéfica de conseqüências, imprevisíveis pelos seus realizadores. 
Realizando o comércio de carne humana, de ouro e pedras preciosas, a bandeira era bem uma emprêsa em sua forma associativa.

Sua constituição apresenta pontos de semelhança com algumas das sociedades comerciais de hoje. Teve ânimo semelhante às Companhias Holandêsas das fndias, que foram o marco inicial da sociedade anônima moderna; todavia, aproximou-se mais, em razão de sua organização e campo de atividades, das atuais sociedades de capital e indústria.

A monção, esta se armava para explorar a penetração pelos rios. Foi, assim, uma emprêsa de transporte fluvial. 